\title{
Promoting EU values in international agreements
}

\author{
Associate professor Eva JANČÍKOVÁ ${ }^{1}$ \\ Assistant professor Janka PÁSZTOROVÁ ${ }^{2}$
}

\begin{abstract}
Within the framework of external relations policy as a subject of international law, the European Union has the right to negotiate, conclude, amend and terminate international agreements on its own behalf, i.e., it has competences granted on it in this area by the Treaties. International agreements concluded at European level are results of an agreement between parties and belong to the sources of European Union Law. Current practice in concluding international agreements at the level of the European Union proves that trade and investment agreements contain provisions concerning civil society, labor relations and environment. The scientific study opens a discussion on a new model of international agreements which, in addition to trade relations, contain provisions on the social status of employees of the parties and on sustainable development. This new model of international treaties is supported by all Member States. The systems analysis shows that the European Union no longer acts as an economic-integration grouping towards third countries, but as an international organization that takes into account high level of environmental protection and the protection of employees' industrial relations.
\end{abstract}

Keywords: EU values, International Agreements, globalization, internationalization.

JEL Classification: K10, K12, K33

DOI: $10.24818 / \mathrm{TBJ} / 2021 / 11 / 2.04$

\section{Introduction}

Globalization, internationalization and the openness of national economies help the process of developing mutual relations. The process of European economic integration is constantly deepening and new forms of cooperation - cooperation with non-member countries from different continents of the world, are coming to the fore. Globalization is helping to develop exchange of goods and services. Globalization enables the development of international investment relations and provides for the movement of capital. ${ }^{3}$ Globalization is becoming part of all processes. Matúšová states that "the ongoing process of globalization encourages the intensive

\footnotetext{
${ }^{1}$ Eva Jančíková - Faculty of International Relations, University of Economics in Bratislava, Slovakia, eva.jancikova@euba.sk.

2 Janka Pásztorová - Faculty of Commerce, University of Economics in Bratislava, Slovakia, janka.pasztorova@euba.sk.

${ }^{3}$ Geistlinger Milan and Nováčková Daniela.2018. Protection of foreign investments in Slovakia. In: Innovation management and education excellence through vision 2020: 31 st International Business Information Management Association Conference (IBIMA 2018), 2018, p. 329-33. Milan, Włochy, ISBN 978-0-9998551-0-2. https://ibima.org/accepted-paper/protection-of-foreign-investment-inslovakia/.
} 
development of trade, global communication networks and technologies. The processes of globalization have intensively connected the world and form the foundations of global civilization". ${ }^{4}$ It is not always possible to look at globalization from a positive perspective. According to Pavelka "the globalization of international business, in addition to the positive effects in the area of more affective use of the comparative advantages of economies, also brings negative externalities in the form of financialization". "Doing business in a global environment is determined, among other things, by the relevant legal framework and has a broader context. Not only states, international organizations, but also other entities, especially multinational companies, participate in the development of international business. The legal framework for conducting business in a global environment is based to a greater extent on international treaties, conventions and legal acts of international organizations and on national legislation. ${ }^{6}$

In order to develop trade, investment, social and cultural relations, the European Union and its Member States are concluding new agreements to facilitate international cooperation. The system of concluding international agreements is coordinated by the European Commission with the cooperation of its Council. All contractual documents are the subject of negotiations in the European Parliament's committees and are also approved at European Parliament level. In this process, Member States are externally represented by the European Union, although they have the right to comment on draft international treaties. Trade agreements with an international dimension respect the rules of international trade set out in the Agreement on World Trade Cooperation (1995) in many areas. Trade relations concern not only the exchange of goods, but also intellectual property rights, product labeling, certification, standards and other areas, and for this reason agreements have more than 100 pages. Economic liberalization rules, meanwhile, may limit the effectiveness of environmental agreements. ${ }^{7}$ For this reason, the European Union calls for a balance to be struck between economic and environmental interests in the development of economic cooperation.

\section{Aims and metodology}

The aim of this scientific study is to identify international treaties concluded by the European Union and its Member States, on the one hand, and other subjects of international law, including the values set out in Article 2 of the EU Treaty. Considering that the European Union (then the European Communities) has concluded several important international treaties in the past, we have focused on the

\footnotetext{
${ }^{4}$ Matušová, Silvia. 2014. Udržatel’nost' hodnôt a hodnoty udržatel'nosti. Ivanička, Koloman et al. Trvalá udržatel'nost' v rozvoji Slovenska. Bratislava: Wolters Kluwer, p. 256.

${ }^{5}$ Pavelka, Luuboš. 2009. Kríza globálnej finacializácie a nová finančná architektúra. In Ekonomický časopis/Journal of Economics, Vol. 57, no. 9, pp. 804-820.

${ }^{6}$ Milošovičová Petra, Nováčková Daniela and Weferová Jarmila. 2017. Medzinárodné ekonomické parvo. Praha: Wolters Kluwer, 2017.

7 Werksman, Jacob, Baumert, Kevin A. \& Dubash, Navroz K. 2003. Will International Investment Rules Obstruct Climate Protection Policies? An Examination of the Clean Development Mechanism. International Environmental Agreements: Politics, Law and Economics 3, 59-86 (2003). https://doi.org/10.1023/A:1021382618537.
} 
period since 2016. The objects of research are the provisions of international treaties relating to democracy, the rule of law, human rights, sustainable development, good development and governance and respect for the environment. In elaboration of the theoretical part, we used mainly classical scientific methods due to its descriptive character. We used the method of structured observation, determining in advance the category of international agreements concluded by the European Union and Member States.

There are several major routes - through the conclusion of international agreements - for EU primary and secondary law to penetrate into third countries' legal orders: the incorporation of the provisions of EU law into international agreements or acts of co-operation bodies set up within the framework of such agreements and references by the international agreements or by co-operation bodies' acts to provisions of EU primary and secondary law.

Through systematic analysis, we have clarified the phenomena and processes related to the conclusion of international agreements at the level of the European Union. The analysis itself is based on the rules of legal logic, systematics, accuracy and the possibility of generalizing conclusions. The synthesis allowed us to connect the links between the knowledge gained in the field. They interprete their legal meaning through deduction. By methods of generalization, we have clarified the exclusive competence of the European Union to conclude international agreements. Method of specification, or concretization was used to identify agreements containing the values of the European Union. Using abstraction, we have defined general and essential information about some trends in international contractual law. By comparative method, we make available different opinions on the legal regulation and interpretation of the researched concepts. The analysis and interpretation of the obtained results prove that the system of concluding international agreements at the level of the European Union is changing, as well as their content.

\section{International treaties}

International treaties are tools for the development of cooperation between states and international organizations and generate rights and obligations for the contracting parties ("parties") as negotiated between them. Treaties form the basis of most parts of modern law. They serve to satisfy a fundamental need of States to regulate by consent issues of common concern, and thus to bring stability into their mutual relations. As an instrument for ensuring stability, reliability and order in international relations, treaties are one of the most important elements of international peace and security. ${ }^{8}$ There are currently several definitions for the term international treaty, but the most commonly used definition is that used in The Vienna Convention on the Law of Treaties9. Article 2 (1) (a) Vienna Convention defines a treaty as "an international agreement concluded between States in written

\footnotetext{
${ }^{8}$ Dörr, Oliver; Schmalenbach, Kirsten. 2012. "Introduction: On the Role of Treaties in the Development of International Law", Vienna Convention on the Law of Treaties: A Commentary, Springer Berlin Heidelberg, pp. 1-6, doi:10.1007/978-3-642-19291-3_1.

${ }^{9}$ United Nations. 1969. Vienna Convention on the Law of Treaties, 23 May 1969, United Nations, Treaty Series, vol. 1155, p. 331, https://www.refworld.org/docid/3ae6b3a10.html.
} 
form and governed by international law, whether embodied in a single instrument or in two or more related instruments and whatever its particular designation". In other words, under international law of treaties, a treaty is any legally binding agreement between states (countries) in written form. International treaty can be called an agreement, a contract, a covenant, a convention, a pact, or a protocol, memorandum of understanding; it is the content of the agreement, not its name, which makes it a treaty. Outrata, a leading Czech expert on public international law, defines international treaties as "an expression of the consensual will of two or more States establishing, amending or cancelling their mutual rights and obligations" 10 . Nováčková states that "international treaty is a legal expression for various forms of cooperation and mutual relations between states or other subjects of international law in the economic, social, cultural, legal, scientific and technical and, last but not least, political areas" $" 11$.

In a broader context, we can say that international treaties are instruments for the development of international cooperation in various areas where parties apply a certain regime. One of the principles for the correct implementation of international treaties is a universal rule, i.e., the principle pacta sunda servanda.

The status of the EU's international agreements in the EU legal order is characterized by a duality: on the one hand, primary law regulates these agreements (as opposed to other legal sources of international law), so their situation is in principle regulated; on the other hand, deeper issues concerning their scope and hierarchical position are not settled by the Treaties. ${ }^{12}$

We believe that all commitments should be honored in good faith and that the parties should not rely on litigation to resolve disputes. The principle of respecting international treaties in good faith has a long history. The conscientious fulfillment of commitments must be carried out honestly and accurately. Only in this case can the fulfillment of international legal obligations be considered bona fide. In general, the rule is that ignorance of the law (legal error) is not an excuse; respectively the rule of liability for violation of the law applies. The registration of international treaties under Article 102 of the UN Charter is ensured by the United Nations. The coordination of the conclusion of international treaties in Slovakia is ensured by the Ministry of Foreign Affairs and European Affairs of the Slovak Republic.

\section{Conclusion of international treaties at the European Union level}

The growing pace of globalization in the world economy has brought significant changes and new challenges for the national economics worldwide. ${ }^{13}$

${ }^{10}$ Outrata, Vladimír. 1960. Medzinárodné právo verejné, ORBIS Praha. p. 297.

${ }^{11}$ Nováčková, Daniela. 2011. International economic Law. Eurounin. Bratislava, p. 29.

12 Mohay Agoston. 2017. The Status of International Agreements Concluded by the European Union in the EU Legal Order. Pregledni znanstveni rad UDK 341.24:061.1(4-67 EU) 341.645(4-67 EU):341.98 DOI: https://doi.org/10.25234/pv/5534. Rad primljen: 2. kolovoza 2017.

${ }^{13}$ Nováčková, Daniela, Saxunová, Darina and Strážovská, L’ubomíra. 2016. Global investment projects implemented in public interest in Slovakia. In Proceedings of Globalization and its socio-economic consequences: international scientific conference [16th], 5-6 Oktober 2016. Rajecké Teplice, Slovakia, 1521-1529 
Globalization has brought the spirit of breaking down cultural and social barriers between people and particularly has accelerated communication and economic cooperation between states. ${ }^{14}$ Within the framework of the EU's external relations policy as subject of international law, the European Union has the right to negotiate, conclude, amend and terminate international agreements on its own behalf, i.e. EU has the competences which has been granted by the Treaties.

International treaties differ from the primary law (the Treaties establishing the European Communities) as well as the secondary EU legislation and form a sui generis category. International agreements should apply throughout the EU. They are more legally binding than unilateral secondary acts, which must therefore comply with them.

The legal basis for concluding international treaties is set out in Articles 3, 4, 207, 216 of the Treaty on the Functioning of the European Union. In accordance with Art. 216 TFEU also constitutes a source of EU law in international agreements concluded between the EU and one or more third countries or international organizations where this is provided for in the Treaties or where the conclusion of an agreement is necessary to achieve the objectives set out in the Treaties in a legally binding EU act, or it may affect the common rules or change their scope. The EU's competence to be a party to international treaties also follows from the provisions of Art. 3 Par. 2 TFEU. If the subject of the treaty does not fall under the exclusive competence of the EU, the agreement must also be signed by the EU countries. These are so-called "mixed agreements".

The structure of treaties concluded at the level of the European Union is relatively broad:

a) Treaties concluded between the European Union and the candidate countries, where they are expected to become Member States;

b) Treaties on full membership of the European Union - Accession Treaties;

c) Treaties concluded with Member States for the purpose of stabilization, where it is not expected to become Member States;

d) Agreements concluded with ACP (African, Caribbean and Pacific) countries in support of development in those states;

e) Economic cooperation and investment protection agreements with third countries.

These types of agreements are published in the Official Journal of the European Union and are publicly available on the European Union's website. Treaties concluded by the European Union are published in the languages of the Member States.

\section{European values}

Matúšová states that the "Treaty of Lisbon" unequivocally declared a Europe of rights and values. Human dignity, freedom, democracy, equality, the rule of law, and respect for human rights are fundamental values of the European Union

\footnotetext{
${ }^{14}$ Spahiu, Artan. 2012. Arbitration proceedings under international regime an overview on the Albanian legislation. In Juridical Tribune - Tribuna Juridica, Vol. 2(2), 2012. p.12.
} 
enshrined in the preamble to the Treaty of Lisbon. The Treaty of Lisbon also emphasizes the importance of the principles on which the European Union is based in its functioning. These are the principles of democracy, the rule of law, human rights and fundamental freedoms, the protection of human dignity, as well as the principles of equality and solidarity. ${ }^{15}$ The process of economic globalization and international integration results in significant changes in the quantity and quality of economic and social processes, as well as the basic principles of a market economy. ${ }^{16}$ Not only the development of European economic relations, but also values is placed great emphasis.

The values of the European Union are common to all Member States and are of great importance to European law. Article 2 of the Treaty on European Union regulates the value base, which significantly affects the fulfillment of its other objectives, as well as the functioning of the EU and the exercise of powers by the individual EU institutions in relation to Member States and citizens of the Union. According to Article 2 of the TEU the Union is founded on the values of respect for human dignity, freedom, democracy, equality, the rule of law and respect for human rights, including the rights of persons belonging to minorities. These values are common to the Member States in a society in which pluralism, non-discrimination, tolerance, justice, solidarity and equality between women and men prevail.

These values are also important in negotiating the candidate country's accession to the European Union. The revision of the negotiating chapters places great emphasis on the fulfillment of criteria such as democracy, the rule of law and the protection of human rights. Member States have an obligation to respect these values and non-compliance can be sanctioned. EU Member States shall, in accordance with the principle of loyalty, take measures of a nature consistent with the tasks and objectives of the Union. ${ }^{17}$

According to Article 7 of the EU Treaty, the Heads of State and Governments in the European Council must first unanimously determine the existence of any serious and persistent breach of the values and principles of the Union. Heads of State and Governments shall determine this on any proposal from one third of the Member States or of the European Commission and after obtaining the consent of the European Parliament. The Council may then, acting by a qualified majority, suspend in respect of the Member State concerned certain rights deriving from the application of the EU Treaty and the TFEU, including the right to vote in the Council. Regarding the understanding of the rule of law within the EU, the most appropriate document is COMMUNICATION FROM THE COMMISSION TO THE EUROPEAN PARLIAMENT AND THE COUNCIL A new EU Framework to strengthen the Rule of Law. The principle of the rule of law law has progressively become a dominant organizational model of modern constitutional law and

\footnotetext{
15 Matúšová, Silvia. 2013. Globálne, európske, psychologické a pedagogické dimenzie hodnôt a kultúry. s. 399.

${ }^{16}$ Staněk, Peter and Stanek, Vojtech. 2005. Globalizácia a jej sociálne súvislosti. In Economic Journal. Bratislava. Vol.35. No. 2/2005. p. 171.

${ }^{17}$ Wefersová, Jarmila, 2016. Správne uplatňovanie práva EÚ v oblasti zdravotníctva na Slovensku. In Hradec economic days. Hradec Králové, p. 220.
} 
international organizations (including the United Nations and the Council of Europe) to regulate the exercise of public powers. ${ }^{18}$

Part of the Rule of Law is the Annex 1: rule of law as the fundamental principle of the EU. This annex clarifies in a broader context the rule of law in the context of the case law of the Court of Justice, which is relatively rich. In this context, the following principles apply:

a) The principle of legality, which essentially includes a transparent, accountable, democratic and pluralistic procedure aimed at implementing legislation. ${ }^{19}$

b) The principle of legal certainty, which requires, inter alia, that legislation be clear and predictable and that it cannot be changed retroactively. ${ }^{20}$

c) The principle of non-arbitrariness. ${ }^{21}$

d) The principle of independent and effective judicial review, including respect for fundamental rights. ${ }^{22}$

e) The principle of the right to a fair trial. ${ }^{23}$

f) The principle of equality before the law. ${ }^{24}$

The European Union also strengthens citizens' rights by stipulating in Article 2 TEU that it will become an area of freedom, security and justice for citizens without internal borders. These values have also become the subject of the provisions of trade agreements concluded by the European Union. At the same time, within the meaning of Article 3 of the TEU, the sustainable development of Europe is based on balanced economic growth and price stability, a highly competitive social market economy, aiming at full employment and social progress, and high level of protection and improvement of the quality of the environment. ${ }^{25}$ Agreements with an international dimension are large in terms, of the number of parties and are designed in a modern language style. The current process of European integration is evolving dynamically, but at the same time it is deepening and gradually forming areas of common policies, common interests and common principles of the rule of law.

${ }^{18}$ European Union. 2014.COMMUNICATION FROM THE COMMISSION TO THE EUROPEAN PARLIAMENT AND THE COUNCIL. A new EU Framework to strengthen the Rule of Law. https://eur-lex.europa.eu/legal-content/EN/TXT/?uri=CELEX:52 014DC0158.

${ }^{19}$ Court of Justice. Case-C-496/99 P, Commission/CAS Succhi di Frutta, Coll. 2004, p. I-03801, recital 63.

${ }^{20}$ Court of Justice. Case - C 212 - 217/80, Amministrazione delle finanze dello Stato/Salumi, Coll. 1981, p. 2735, recital 10.

${ }^{21}$ Court of Justice. Case C- 46/87, 227/88, Hoechst/Commission Coll.1989, p. 02859, recital 19.

${ }^{22}$ Court of Justice.Case -C-583/11 P, Inuit Tapiriit Kanatami a i./Parliament ams Council, recital 91; Court of Justice. Case C-550/09, E and F, Coll. 2010, p. I-06213, recital 44; Case C-50/00 P, Unión de Pequeños Agricultores, Coll. 2002, p. I-06677, recital 38 and 39.

${ }^{23}$ Court of Justice. Case C-174/98 P and C-189/98 P, Kingdom of the Netherlands and Gerard van der Wal v. Commission of the European Communities-Coll. 2000, p. I-00001, recital 17.

${ }^{24}$ Court of Justice. Case- C-550/07 P, Akzo Nobel Chemicals a Akcros Chemicals/Commission Coll. 2010, p. I-08301, recital 54.

${ }^{25}$ Consolidated version of the Treaty on European Union. Official Journal C 326, 26/10/2012 


\section{Trade agreements concluded at the European Union level}

In view of the stated objective, we have focused on agreements that contain provisions relating to the values of the European Union and explicitly provide for their protection. The diction of the application of values by the Member States is not only under the direction of the European Union, but similar values are also recognized by the Council of Europe.

The European Union has concluded trade agreements of international importance in several countries around the world. We focused on the following agreements:

1. The Free Trade Agreement between the European Union and the Socialist Republic of Viet Nam (FTA between EU and Vietnam, 2020);

2. Comprehensive Economic and Trade Agreement (CETA) between European Union and Canada, 2017);

3. Free Trade Agreement between the European Union and the Republic of Singapore (FTA between EU and Singapur, 2019).

The International Agreement (draft) between the European Union and its Member States and the Socialist Republic of Vietnam ${ }^{26}$ has been regularly consulted with the Member States. According to the Preamble, the Agreement in question contributes to the harmonious development and expansion of international trade by removing barriers to trade. The Trade Agreement also contains important provisions on the protection of intellectual property, labor rights and sustainable development. The FTA also includes commitments to implement core International Labour Organisation (ILO) standards and UN conventions on, e. g., combating climate change or protecting biodiversity. Based on Article 1.1 of the EU-Vietnam Agreement, the aim of the Agreement is to establish a free trade area, in accordance with Article XXIV of GATT 1994 and Article V of GATS. This means that import and export duties and other measures affecting the development of trade relations will be phased out.

The objectives of the EU-Vietnam Agreement are to liberalize and facilitate trade and investments. The parties have committed themselves to liberalizing the markets in the territories of the parties, where competition rules apply. At the same time, they confirmed by mutual agreement that they would enable the development of investment relations with a view to non-discrimination and the most-favorednation clause. The Agreement in question entered into force on $1^{\text {st }}$ of August 2020 and represents a great opportunity for Slovak exports and barrier-free trade.

This Agreement contains provisions on national treatment, on the elimination of customs duties, on remedial measures in the field of trade, on the most-favored-nation clause, on electronic commerce, on public procurement, on the protection of intellectual property rights, on dispute resolution, etc. and includes annexes which contain specific forms of cooperation in specific areas, such as a timetable for tariff reductions.

${ }^{26}$ European Union. Free Trade Agreement between the European Union and the Socialist Republic of Viet Nam. OJ L 186, 12.6.2020, p. 3-1400. 
Promoting sustainable development is in the spotlight of the United Nations, and also of the European Union and its Member States. The World Commission on Environment and Development, in the Brundtland report entitled Our Common Future of 1987, defined sustainable development as "development that meets the needs of the present without compromising the ability to meet the needs of future generations." The aim is to reconcile economic development with the protection of social and environmental balance. ${ }^{27}$ Chapter 13 of the EU-Vietnam Agreement contains provisions on trade and sustainable development. This means that any economic activity will have to be carried out in accordance with the sustainable development and environmentally friendly.

It will be the duty of the parties to ensure that national environmental legislation complies with international standards and will respect multilateral international environmental agreements. In this context, it is mainly a policy of reducing emissions, decarbonisation and building a low-carbon economy in general. This obligation is also financially demanding, as it requires the introduction of new blue environmentally friendly technologies.

The green investment system is becoming a new trend nowadays and the parties have embarked on the path of building a modern and competitive green economy. The Parties are expected to promote resource efficiency through the transition to a clean circular economy. As stated by Strážovská, many provisions mention economic and social development, which can be understood as a balance between the economic and social interests of the parties. ${ }^{28}$ It is in this context that we have the opportunity to see that the European Union's action has not only an economic dimension but also a social dimension. ${ }^{29}$ Economic and social development is mentioned in many provisions, which can be understood as balance between the parties' economic and social interests.

There is s special provision in this Agreement on corporate social responsibility. (13.14. EU-Vietnam agreements). The Institute of Corporate Social Responsibility is relatively important, especially in terms of environmental protection and the protection of workers' rights. It is a modern approach to innovation, in particular involving an effective and responsible approach to the components of investment developed for society, employer-employee relations, creativity, sustainability of jobs, and concern for the environment. In principle, the institute is based on a relationship - entrepreneurship, so that a wide range of people benefit from the processes and results of entrepreneurship. In the social area of corporate social responsibility, these are primarily social rights, health care and safety for employees.

From the point of view of the protection of workers' rights and the protection of social rights, the parties prefer that employees perform work activities in a decent working environment, so that they have the right to freedom of association, the right

${ }^{27}$ EUR-LEX. 2020. Glosár súhrnov. https://eur-lex.europa.eu/summary/ glossary/ sustainable development.html?locale $=$ sk.

${ }^{28}$ Strážovská, Lubomíra and Trel'ová, Silvia: Small and medium-sized business - legal form of business in Slovakia. In: Economics, management, Law: Innovation strategy. - Zhengshou: Henan Science and Technology Press, 2016. p. 82-85.

${ }^{29}$ Kovalančíkova, V. 2014. Social oriented market and social economy. In Hradec economic days 2014. Hradec Králové University, p. 57. 
to collective bargaining. It is noteworthy that the EU-Vietnam Agreement also contains a provision on the elimination of all forms of forced labor or a ban on child labor (13.4). It is not customary in contractual practice for agreements to contain provisions on the prohibition of forced labor or the prohibition of child labor. Since its inception, the European Union has emphasized the prohibition of discrimination on grounds of nationality and the prohibition of any discrimination.

Such a prohibition is relatively broadly regulated in primary and secondary legislation. It is also part of the contract in question in connection with the elimination of discrimination in respect of employment and occupation. In general, it can be stated that the prohibition of discrimination is regulated in several international agreements. In the Slovak legal system, after the accession to the European Union, Act no. 365/2004 Coll. on equal treatment in certain areas and on protection against discrimination (Anti-Discrimination Act) was adopted.

It is also worth mentioning the area of cooperation in the field of exchange of information and experience related to trade and sustainable development in order to prepare and implement activities related to cooperation and capacity building. This means that international cooperation should also be reflected in building of administrative capacity, which will be directly involved in the implementation of the agreement. Specific forms of cooperation will take the form of workshops, seminars, training and dialogues for the exchange of knowledge and experience.

Current contractual practice in trade does not recognize that the parties have included in the subject of their cooperation the issues of human resources development and lifelong learning, social protection for all, including vulnerable and disadvantaged groups such as migrant workers, women, young people and people with disabilities, and social inclusion, social dialogue and gender equality. There are several areas of cooperation that are interconnected, because both parties want not only the economic development of relations, but also the development of social relations and education.

Another important agreement is the Comprehensive Economic and Trade Agreement (CETA) ${ }^{30}$ between the European Union, the Member States of the European Union and Canada.

CETA establishes legal framework on international level for elimination of customs duties, access to public tenders, opens market with services, creates suitable conditions for development of investment relations, and helps to prevent illegal copying of innovations and traditional EU products. This Agreement also contains all the guarantees to ensure that economic benefits are not realized to the detriment of fundamental rights, social standards, the government's right to regulate, environmental protection or the health and safety of consumers.

The CETA Agreement contains a new modern EU approach to investment protection and an investment dispute settlement mechanism. It introduces important innovations in this area, ensures a high level of investor protection, while fully preserving the right of governments to regulate and enforce legitimate public policy objectives in terms of health, safety or the environment. Being in line with European Union policies, this Agreement contains provisions on trade and sustainable

${ }^{30}$ European Union. Comprehensive Economic and Trade Agreement (CETA). https:/lec.europa.eu/ trade/policy/in-focus/ceta/. 
development, trade and labor standards, and trade and the environment, which links it directly to the EU's overall sustainable development goals.

The purpose of the CETA Agreement is to establish a free trade area in conformity with Article XXIV of GATT 1994 and Article V of the GATS. In terms of comparison, the objective of the said Agreement is in line with the EU-Vietnam agreement. Considering the objective of our research, we focused on trade and sustainable development, which is regulated in Chapter 22 of the CETA. In the CETA, the parties undertook to promote sustainable development through enhanced coordination and integration of their labor, environmental and trade policies and measures.

A special feature of the CETA are the provisions of Article 22.5 on civil society, which is intended to establish a framework for the functioning of independent organizations representing employers, trade unions, labor and business organizations, environmental groups and, where appropriate, other civil society organizations. In principle, the provisions on public policy are also part of the agreement on trade and investment, which can be included in economic agreements in terms of substantive focus. Civil society is an important pillar of democracy in society and is independent of public power. On the basis of this Agreement, relations will be formed at the level of business and non-profit sectors with an international dimension.

The parties have also entered into commitments in the field of employment relations concerning decent work, including core labor standards and high level of protection of health at work, while the parties will create the conditions for the provision of measures relating to freedom of association, collective bargaining and the association of child labor. At the same time, all forms of discrimination, including migrant workers, are expected to be eliminated. This raises the question of who is considered a migrant, because the European Union has its own instruments in the context of migration policy, even though the objectives of the European Union's migration policy are in line with those of the United Nations.

It is worth noting that today, countries with high standard of living and economically prosperous international treaty will incorporate provisions banning the employment of children. We are certain that child labor at national level is prohibited in the EU Member States and Canada. The similar situation is in the prevention of threats to human lifes or health.

The parties have agreed on common procedures for the protection of the environment and have committed themselves to contaminating the soil and polluting the environment as little as possible. It is already becoming an international contract practice that cooperation at the international level in the field of trade and investment will be determined by sustainable development and environmental protection.

In this context, we can also talk about green trade and on the efficient use of natural resources. Management of global environmental resources is a difficult task 
because binding rules have to be agreed upon internationally but need to be implemented at the national level. ${ }^{31}$

Corporate social responsibility is also part of the parties' joint agenda. It is interesting how the parties impose an obligation on entrepreneurs, in the form of an international agreement, to emphasize the social protection of workers' rights and the protection of the environment in their business. This provision obliges the parties to ensure such conditions that the companies' economic activities will have a rational concept on which it will be possible to build the sustainable development of the company.

In our paper, we analyze the third trade agreement regulating EU values, namely the Free Trade Agreement between the European Union and the Republic of Singapore ${ }^{32}$.

This Agreement entered into force on 21 November 2019. This international agreement, like the two previous ones, establishes a free trade area between the EU and the Republic of Singapore, with aims being to liberalize and encourage trade and investment between the agreement partners. From a territorial point of view, it is interesting that the European Union is focused on cooperation with the countries of the Asian continent.

Negotiations for trade agreement between the EU and Singapore were concluded in 2017. In view of the Opinion of the Court (Full Court) of 16 May 2017 AVIS $2 / 15^{33}$ on the division of competences between the European Union and the EU Member States, the original draft of Trade and Investment Agreement was divided into two separate equivalent agreements:

a) The Free Trade Agreement between the European Union and the Republic of Singapore falls within the exclusive competence of the European Union.

b) Investment Protection Agreement between the European Union and its Member States, on one part, and the Republic of Singapore, of the other part (Foreign direct investment); competences are shared between the European Union and the Member States.

The Agreement on Trade and the Agreement on Investment Protection were signed on 19 October 2018 and subsequently submitted to the European Parliament for assent. The European Parliament approved the agreement on 13 February 2019. The FTA has been in force since 21 November 2019, is quite extensive, has a total of 755 pages and many annexes.

As the Investment Protection Agreement is a mixed competence of EU in the national parliaments of the EU Member States. The Trade Agreement contains provisions on economic, social development and environmental protection, which are interlinked and mutually reinforcing components of sustainable development. It

\footnotetext{
${ }^{31}$ Alvarado-Quesada, Irene and Weikard, Hans-Peter. 2017. International Environmental Agreements for biodiversity conservation: a game-theoretic analysis. Int Environ Agreements 17, 731-754 (2017). https://doi.org/10.1007/s10784-017-9368-7.

32 European Union. Free trade agreement between the European Union and the Republic of Singapore OJ L 294, 14.11.2019, pp. 3-755).

${ }^{33}$ OPINION 2/15 OF THE COURT (Full Court) 16 May 2017. ECLI:EU:C:2017:376.
} 
also emphasizes the benefits of cooperation on trade-related social and environmental issues as part of a global approach to trade and sustainable development. The agreement will clearly facilitate and support trade and investment in environmental goods and services, including through the removal of related nontariff barriers.

The Agreement includes, inter alia, a chapter on trade and sustainable development, which aims to ensure that trade supports environmental protection and social development and promotes the sustainable management of forests and fisheries. The chapter 12 also sets out how social partners and civil society should interact. The parties consider it important that attention is to be paid not only to economic development but also to decent work and social justice.

Economic and social development and environmental protection are interlinked and mutually reinforcing components of sustainable development. They emphasize the benefits of cooperation on trade-related social and environmental issues as part of a global approach to trade and sustainable development. Elimination of all forms of discrimination, employment of children is a specific agenda of mutual cooperation between the parties.

The Trade Agreement contains a specific provision on corporate social responsibility, which is adopted on a voluntary basis. In this context, the Parties undertake to exchange information and cooperate in order to promote corporate social responsibility.

The Agreement contains ANNEX 9-I entitled Public-Private Partnerships. It is not typical practice of international contracting for public-private partnerships to be part of an international agreement. This Agreement supposes cooperation between public sector and private sector, the aim which is to provide high quality public services and infrastructure wherever their justification can be demonstrated, using the resources and capacities of the private sector. To a large extent, it is an alternative form of public procurement.

The following table illustrates the systemic features of the conformity of international treaties concluded by the European Union and its Member States, on the one hand, and non-member countries, on the other. All contracts are quite extensive, containing more than 700 pages.

Comparison of EU values regulated in international treaties

\begin{tabular}{|l|l|l|l|l|}
\hline Trade agreement & $\begin{array}{c}\text { Protection of } \\
\text { human } \\
\text { rights }\end{array}$ & $\begin{array}{c}\text { Prohibition of } \\
\text { discrimination }\end{array}$ & $\begin{array}{c}\text { Sustainable } \\
\text { development, } \\
\text { environment }\end{array}$ & $\begin{array}{c}\text { Civil Society } \\
\text { Forum, social } \\
\text { responsibility }\end{array}$ \\
\hline EU and Vietnam & $\mathrm{X}$ & $\mathrm{X}$ & $\mathrm{X}$ & $\mathrm{X}$ \\
\hline EU and Canada & $\mathrm{X}$ & $\mathrm{X}$ & $\mathrm{X}$ & $\mathrm{X}$ \\
\hline EU and Singapur & $\mathrm{X}$ & $\mathrm{X}$ & $\mathrm{X}$ & $\mathrm{X}$ \\
\hline
\end{tabular}

Our findings confirmed that the EU's value base also has a significant impact on external relations policy, while coordination remains within the competence of the European Union. 
The European Union values are common to the Member States and the countries with which it enters into contractual relations. These international agreements provide the legal basis and legislative framework for all-round international cooperation with non-member countries and are also beneficial for the Slovak Republic.

\section{Conclusion}

Even today, Europe and the European Union cannot be considered merely a territory forming under the influence of processes of international economic integration. In the beginnings of integration, Europe is still declared as a territory and community of values of European civilization. Peace and prosperity remain one of the greatest European values. ${ }^{34}$

Based on the above analysis, it can be stated that the values of the European Union regulated in the primary legislation become part of the provisions of international agreements on trade and investment. We have identified three major international agreements that bring new elements to the processes of European integration and contribute to improving the European Union's position among international organizations. Protection of social rights and sustainable development also become part of commercial and investment activities.

Such an attitude of the European Union can be seen as forming a balance between economic interests and social and cultural interests. The current European Union' new approaches in the field of contract law can also be characterized as a deepening of European integration with the help of international treaties, which are becoming instruments of the European Union's external action.

The internal cohesion of the Member States and coordination at European Union level are essential to ensure the performance of the European economy and social justice. The international economic policy formed by the European Union connects the continents of the world and its goal is not only integration duties, but also enhanced cooperation in various areas. The European Union essentially favors global approach to trade and sustainable development.

\section{Bibliography}

1. Alvarado-Quesada, Irene, Weikard, Hans-Peter. 2017. "International Environmental Agreements for biodiversity conservation: a game-theoretic analysis". Int Environ Agreements 17: 731-754. https://doi.org/ 10.1007/s10784-017-9368.

2. COM/2018/691 finalEuropean Union. OJ C 326, 26.10.2012, p. 13-390 European Union. A new EU Framework to strengthen the Rule of Law (COM/2014/0158 final. https://eur-lex.europa.eu/legal-content/EN/TXT/?uri= CELEX: 52014DC0158.

4. $\mathrm{COM} / 2018 / 691$ final European Union: Consolidated version of the EU o fungovani Európskej únie Ú. v. EÚ C 202, 7.6.2016.

${ }^{34}$ Matúšová, S. 2014. Udržatel'nost' hodnôt a hodnoty udržatel'nosti. s. 255. 
6. Consolidated version of the Treaty on European Union. Official Journal C 326, 26/10/2012.

7. Court of Justice. Case-C-496/99 P, Commission/CAS Succhi di Frutta, Zb. 2004, p. I-03801, recital 63.

8. Court of Justice. Case - C 212 až 217/80, Amministrazione delle finanze dello Stato/Salumi, Coll. 1981, p. 2735, recital 10.

9. Court of Justice. Case C- 46/87, 227/88, Hoechst/Commission. Coll.1989, p. 02859, recital 19.

10. Court of Justice. Case -C-583/11 P, Inuit Tapiriit Kanatami a i./Parliament ams Council, recital 91; Court of Justice. Case C-550/09, E and F, Zb. 2010, p. I-06213, recital 44; Case C-50/00 P, Unión de Pequeños Agricultores, Zb. 2002, p. I-06677, recital 38 a 39.

11. Court of Justice. Case C-174/98 P and C-189/98 P, Kingdom of the Netherlands and Gerard van der Wal v. Commission of the European Communities-Coll. 2000, p. I-00001, recital17.

12. Court of Justice. Case- C-550/07 P, Akzo Nobel Chemicals a Akcros Chemicals/Commission Coll. 2010, p. I-08301, recital 54.

13. Dörr, Oliver, Schmalenbach, Kirsten. 2012. Introduction: On the Role of Treaties in the Development of International Law", Vienna Convention on the Law of Treaties: A Commentary, Springer Berlin Heidelberg, pp. 1-6, doi:10.1007/978-3-642-19291-3_1, ISBN 9783642192913.

14. Geistlinger, Michal, Nováčková Daniela, Protection of foreign investments in Slovakia. In: Innovation management and education excellence through vision 2020. $31^{\text {st }}$ International Business Information Management Association Conference (IBIMA 2018), 2018, p. 329-33. Milan, Włochy, ISBN 978-0-9998551-0-2.

15. EUR-LEX 2020. Glossary of summary. https://eur-lex.europa.eu/summary /glossary/sustainable_development. html?locale=sk.

16. European Union. 2014. COMMUNICATION FROM THE COMMISSION TO THE EUROPEAN PARLIAMENT AND THE COUNCIL. A new EU Framework to strengthen the Rule of Law. https://eur-lex.europa.eu/legal-content/EN/TXT/? uri=CELEX:52014DC0158.

17. European Union. Comprehensive Economic and Trade Agreement (CETA). https://ec.europa.eu/trade/policy/in-focus/ceta/.

18. European Union. Free Trade Agreement between the European Union and the Socialist Republic of Viet Nam. OJ L 186, 12.6.2020, pp. 3-1400.

20. European Union. Free trade agreement between the European Union and the Republic of Singapore OJ L 294, 14.11.2019, pp. 3-755.

21. Kovalančíkova, Vlasta. 2015. Sociálne orientované trhové hospodárstvo a sociálne podnikanie. In Hradec economic days 2015. Hradec Králové University, ISBN 978-807435-367-3.

22. Matúšová, Silvia. 2013. Globálne, európske, psychologické a pedagogické dimenzie hodnôt a kultúry. In Jablonský, T., Matúšová, S. a kol. Učitel’ a hodnoty. Európske hodnoty a kultúrne dedičstvo - výzva pre vzdelávanie. Ružomberok: Verbum, $488 \mathrm{~s}$. ISBN 978-80-561-0089-9.

23. Matúšová, Silvia. 2014. Udržatel'nost' hodnôt a hodnoty udržatel'nosti. In Ivanička, Koloman. et al. Trvalá udržatel’nost'v rozvoji Slovenska. 2014. Bratislava: Wolters Kluwer, 309 s. ISBN 978-80-8168-036-6.

24. Milošovičová Petra, Nováčková Daniela and Weferová Jarmila. 2017. Medzinárodné ekonomické parvo. Praha: Wolters Kluwer, 2017. ISBN 978-80-7552-530-7.

25. Mohay Agoston. 2017. The Status of International Agreements Concluded by the 
European Union in the EU Legal Order. In Pregledni znanstveni rad UDK 341.24:061.1(4-67 EU) 341.645(4-67 EU): 341.98 DOI: https://doi.org/10.25234/ pv/5534 Rad primljen: 2. kolovoza 2017.

26. Nováčková, Daniela. 2011. International economic Law. Eurounin. Bratislava. ISBN 978-80-893-74-12-0.

27. Nováčková, Daniela, Saxunová, Darina, Strážovská L’ubomíra. 2016. Global investment projects implemented in public interest in Slovakia. In Proceedings of Globalization and its socio-economic consequences: international scientific conference [16 ${ }^{\text {th }}$ ], ISBN 978 80-8154-191-9, 5-6 Oktober 2016. Rajecké Teplice, Slovakia, 1521-1529.

28. Opinion 2/15 of the Court (Full Court) 16 May 2017. ECLI:EU:C:2017:376.

29. Outrata, Vladimír. 1960. Medzinárodné právo verejné. ORBIS Praha.

30. Pavelka, Luboš. 2009. Kríza globálnej financializácie a nová finančná architektúra. In Ekonomický časopis/Journal of Economics, vol. 57, no.8, pp. 804-820. ISSN 0013-3035.

31. Spahiu, Artan. 2012. Arbitration proceedings under international regime an overview on the Albanian legislation. In Juridical Tribune - Tribuna Juridica. Vol. 2(2), 2012. eISSN 2248-0382.

32. Staněk, Peter and Stanek, Vojtech. 2005. Globalizácia a jej sociálne súvislosti. In Economic Journal. Bratislava. Vol.35. No.2/2005. ISSN: 0013-3035.

33. Strážovská, Lubomíra - Trel'ová, Silvia: Small and medium-sized business - legal form of business in Slovakia. In: Economics, management, Law: Innovation strategy. Zhengshou: Henan Science and Technology Press, 2016. - pp. 82-85. - ISBN 978-6177214-22-8.

34. United Nations. 1969, Vienna Convention on the Law of Treaties, 23 May 1969, United Nations, Treaty Series, vol. 1155, https://www.refworld.org/docid/3ae6b3a10.html.

35. Wefersová, Jarmila. 2016. Správne uplatňovanie práva EÚ v oblasti zdravotníctva na Slovensku. In Hradec economic days. Hradec Králové, ISBN 2464-6040.

36. Werksman, Jacob, Baumert Kevin A. and Dubash Navroz K. 2003. International Investment Rules Obstruct Climate Protection Policies? An Examination of the Clean Development Mechanism. International Environmental Agreements: Politics, Law and Economics vol. 3, 59-86. https://doi.org/10.1023/A:1021382618 537. 